\title{
ARCHAEOLOGICAL HERITAGE AS A CATALYST FOR PUBLIC ENGAGEMENT, RURAL REJUVENATION, AND RETHINKING OUR SHARED PAST: PERSPECTIVES FROM A QUARTER CENTURY OF COMMUNITY ARCHAEOLOGY IN NEWFOUNDLAND AND LABRADOR
}

\author{
Patrimônio arqueológico como catalisador para o \\ envolvimento público, o rejuvenescimento rural e o \\ repensar de nosso passado comum: perspectivas de \\ um quarto de século de arqueologia comunitária em \\ Terra Nova e Labrador
}

\author{
Barry C. Gaulton \\ Lisa K. Rankin*
}

\begin{abstract}
Archaeological research in Canada's easternmost province has enjoyed a long and evolving history of community partnerships. This is due, in part, to Memorial University's unique mandate, as well as the Department of Archaeology's strong commitment to working with individuals and organizations where excavations are conducted. Three case studies from Newfoundland and Labrador shed light on the motivations, experiences, challenges, and outcomes that community-university research partnerships can foster, and demonstrate that archaeology has the potential to make valuable local contributions.
\end{abstract}

Keywords: Archaeology; community-university partnerships; traditional knowledge; rural rejuvenation; social justice.

\footnotetext{
* Department of Archaeology, Memorial University of Newfoundland. St. John's, NL, Canada, A1C 5S7. +1-709-864-8869

E-mail: bgaulton@mun.ca; lrankin@mun.ca
} 


\section{RÉSUMÉ}

La recherche archéologique dans la province canadienne située le plus à l'Est du pays a longtemps profité d'une histoire de partenariats avec les communautés qui a su évoluer dans le temps. Cela s'explique, en partie, par le mandat exceptionnel de la Memorial University, ainsi que par l'engagement prononcé du département d'archéologie pour travailler avec les individus et les organisations locales lors des excavations. À partir de trois études de cas de Terre-Neuve et Labrador, cet article met en lumière les motivations, les expériences, les défis, et les résultats que les partenariats communauté-université peuvent générer, et démontre le potentiel de la discipline archéologique à réaliser des contributions importantes au niveau local.

Mots-clés: archéologie; partenariats communauté-université; savoir traditionnel; rajeunissement rural; justice sociale

\section{RESUMO}

A pesquisa arqueológica na província mais oriental do Canadá se beneficiou de uma longa e expansível história de parcerias com as comunidades. Tal deve-se, em parte, ao mandato excepcional da Memorial University, assim como ao engajamento forte do departamento de arqueologia em trabalhar com indivíduos e organizações locais durante escavações. A partir de três casos de estudos da província de Terra Nova e Labrador, este artigo revela as motivações, as experiências, os desafios, como os resultados que podem surgir das parcerias comunidade-universidade, e atesta do potencial da arqueologia em contribuir localmente de forma vantajosamente.

Palavras-chave: arqueologia; parcerias comunidadeuniversidade; saber tradicional; rejuvenescimento rural; justiça social

\section{Introduction}

The following paper presents an overview of communityuniversity research partnerships on archaeological sites in Canada's easternmost province, Newfoundland and Labrador. Using three culturally and geographically distinct case studies, it demonstrates how this province's archaeological resources play an integral part in engaging the public, in rejuvenating the social and economic fabric of 
rural and Indigenous communities, in working towards reconciliation, and in rethinking the past for the benefit of our shared future.

Memorial University of Newfoundland (MUN) was established as a memorial to those who lost their lives during the First and Second World wars and was designed to help build a better future for the people of the province. As such, it has a unique mandate, which includes the phrase "a special obligation to the people of Newfoundland and Labrador" (MEMORIAL UNIVERSITY, 2013). This obligation prioritized community-based research agendas, promoting social justice at the local scale by providing education; training; economic opportunities; and, more recently, paths toward reconciliation with Indigenous communities. All this began long before community engagement and knowledge transfer were institutionalized elsewhere.

Social scientists at Memorial University embraced applied, community-based research in the years following Newfoundland and Labrador's confederation with Canada (1949), when urbanization and industrialization threatened the continuity of the new province's largely rural lifeways (WEBB, 2015). The initial goals were twofold: to record a way of life before it disappeared, but also to encourage a participatory democracy through which communities could find local solutions to the social and economic issues arising from the transformation to modernity. Archaeologists, operating largely in rural settings, witnessed this disenfranchisement first hand and integrated training, employment, and tourism strategies into their research to assist the communities in which they worked.

Starting in 1979 in Red Bay, Labrador, local residents partnered with MUN archaeologists to unearth, interpret, and preserve the remains of the sixteenth-century Basque whaling industry. These excavations provided summer employment and training opportunities, local businesses thrived, and the discovery became an immense source of pride for the community. The social and economic benefits of the annual archaeological excavations, combined with the national and international interest in these discoveries, transformed this sleepy fishing village into one of Newfoundland and Labrador's premier tourist attractions, first as a designated National Historic Site of Canada, in 1979, and more recently as a UNESCO World Heritage Site, in 2013. 
The early 1990s saw an important shift in the nature of partnerships between archaeologists and the communities in which they conducted research. Following the collapse of the cod fishery in 1992, many communities requested assistance from the university to help find local, culturally appropriate solutions to the ensuing economic crisis. Having witnessed earlier implementations of archaeological tourism, communities came prepared to develop partnerships with the Department of Anthropology (now Department of Archaeology) that formalized co-management strategies that would equalize power relations between academics and locals and ensure that both community and research goals guided the development of archaeological resources (RICHARDSON and ALMANSASÁNCHEZ, 2015). These formalized strategies often spawned notfor-profit community organizations, the members of which - ranging from fishers and business people to teachers and accountants brought valuable perspectives to the table and steered these research partnerships in directions that sought to maximize education and retraining opportunities, increase public input and engagement, develop/expand tourism potential, and maintain an equal stake in how their local history was represented.

More recently, our partnerships with Indigenous communities have taken the process a step further by implementing research agendas established by the communities themselves, helping to centre the Indigenous voice in the presentation of their own history (ATALAY, 2012). These new partnerships have developed around the themes of social justice and reconciliation rather than particular archaeological sites. Their focus is on the creation of a body of archaeological, historical, and cultural material informed by both traditional knowledge and academia that could serve as a community resource used to bolster everything from land claims and identity to education and economic initiatives.

Today, the majority of publicly accessible archaeological sites in Newfoundland and Labrador involve strong community-based management, whether from a community council, not-for-profit foundation, or historical society. The recognized stakeholders have also grown: government officials, the interested public, local historians, avocational archaeologists, sport divers, and descendants of those who lived and worked on the same lands where 
archaeologists conduct their excavations all have a voice in the interpretation, dissemination, and preservation of the past.

These partnerships, and the resultant approaches taken by MUN archaeologists and community stakeholders, are not unique to Newfoundland and Labrador. Notable community-academic partnerships have taken place in many parts of Canada, from the Arctic to the Maritimes to the Prairies (AUGUSTINE et al., 2007; BROOKS, 2007; FRIESEN, 2002). The same can be said for collaborations in the United States at such places as Little Rapids, Minnesota, and Ozette, Washington (KIRK and DAUGHERTY, 1978; SPECTOR, 1993). The partnerships involving MUN are highlighted here for their frequency, longevity, and commitment to social justice. Of equal importance is the fact that both the Government of Newfoundland and Labrador and Memorial University recognize community archaeology as socially, economically, morally, and pedagogically valuable in its own right. We would argue that this provides fertile ground for the further development and application of community-based approaches.

From a conceptual standpoint, the terms "community" and "heritage" are utilized in the broadest possible sense. A community is not easy to define, nor is it monocultural or necessarily unified in thought or purpose (JAMESON and BAUGHER, 2007, p. 4-5; MARSHALL, 2002, p. 215). As outlined by Marshall (2002, p. 216), two kinds of community often emerge as a result of archaeology: nearby residents with a stake in the project and/or descendants of those who once occupied the lands under investigation. These two communities are not mutually exclusive, nor do their interests fully represent the goals of other stakeholder groups; however, this dual construct provides a useful starting point for the following discussion. Heritage is an equally problematic and diffuse concept, but one which can be envisioned in both its tangible and intangible forms, encompassing everything from landscapes, seascapes, oral histories, and traditional knowledge to excavated hearths and stone walls, preserved flora and fauna, and extant buildings. 


\section{Case Study 1: An evolving partnership at Ferryland, Newfoundland}

Our first case study is the archaeological site at Ferryland, Newfoundland, located on the east coast of Newfoundland's Avalon Peninsula. Much of the research on Ferryland has focused on the 1621 colony established by Sir George Calvert (the 1st Lord Baltimore) and the succeeding plantation of Sir David Kirke and family, from 1638 to 1696 (GAULTON, 2013; GAULTON and TUCK, 2003; TUCK, 2013; TUCK and GAULTON, 2013). This site is a treasure trove of information because Ferryland is an archaeologically rich and well-preserved seventeenth-century North American colony for which there are only a handful of primary sources. Archaeological investigations have demonstrated that Ferryland was occupied for at least 100 years prior to official colonization in 1621. So it is through excavation that we are obtaining a more holistic understanding of all the past residents of this community - including the Beothuk, the Indigenous people who lived on what is now the island of Newfoundland, as well as migratory fishers from Europe - and each group is represented through our program of interpretation and dissemination.

Large-scale archaeological investigations at Ferryland coincided with the 1992 Atlantic cod moratorium, an event that forced approximately 25,000 fishers and plant workers in Newfoundland and Labrador to abandon their traditional livelihoods (GIEN, 2000, p. 121). The moratorium "triggered the largest industrial closure in Canadian history," and many rural communities hit rock bottom socially and economically (DOLAN et al., 2005, p. 202). A federal-provincial agreement had already been put in place in 1991 to excavate the Ferryland site, and this academic research, slated to begin in 1992, had the added benefit of providing employment and retraining opportunities for community members in both Ferryland and the surrounding region (TUCK, 1993, p. 296). Locals were trained in archaeological fieldwork techniques, the conservation and stabilization of artifacts, and best practices in collections management. Following the formative years of the early 1990s, as 
more was uncovered, interpreted, and made available to the public, our vision for the Ferryland site evolved, in close collaboration with staff and community members.

The local not-for-profit Colony of Avalon Foundation was established in 1994 with a mandate to "investigate, interpret, preserve and develop the archaeological remains of Lord Baltimore's Colony of Avalon." Volunteer board members from all walks of life, working within the parameters of the Foundation's core mandate - and in close collaboration with archaeologists from Memorial University - strove to make this archaeological site a key tourist attraction for the region. Of equal importance was the fact that we as archaeologists sought to make it a source of collective pride for the community and a way to embrace our past to build a viable and vibrant future. In partnership with the Foundation, our level of interpretation, public dissemination, and infrastructure grew in leaps and bounds, spurring subsequent growth and diversification at the community level.

Within five years, an interpretation centre, conservation lab, and collections room were built not far from the archaeological site to display, conserve, and store our finds. Guided tours were available throughout the summer months, and three heritage gardens - a gentlemen's garden, herb garden, and kitchen garden - were established using period plans and construction techniques. A gift shop was opened, and directly behind it, a reproduction seventeenthcentury kitchen room, staffed by costumed interpreters who educate visitors about the challenges of life in Newfoundland during the early modern period. Integrated into the kitchen's interpretative program are reproductions of ceramic and glass vessels and clay tobacco pipes found during the excavations. 
Figure 1

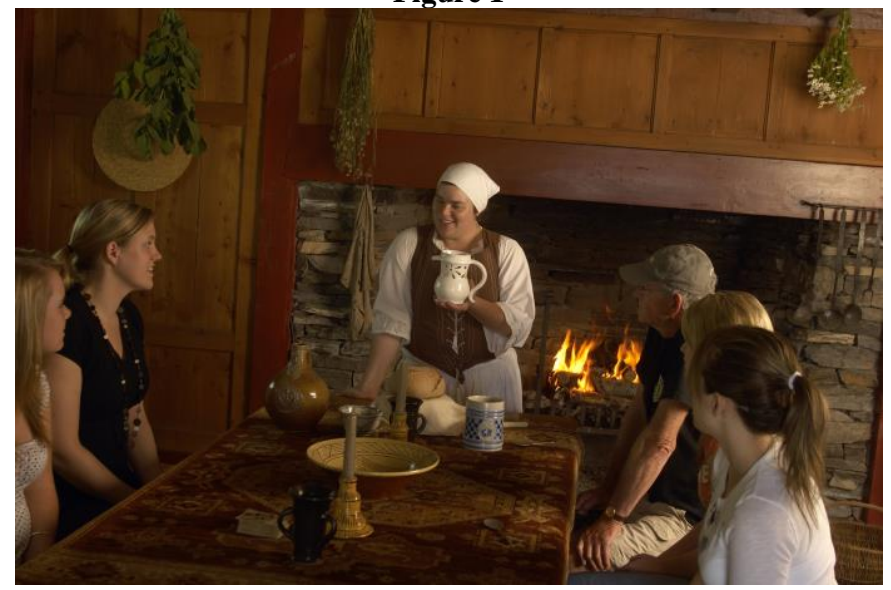

Costumed interpreter Lori Pittman demonstrating how a seventeenth-century puzzle jug works. The jug is a reproduction of a vessel found during excavations at Ferryland. Image courtesy of the Colony of Avalon Foundation.

Visitors learn about where and when the original historic objects were made, how they were used, and where on the site they were found, allowing them to directly relate to the processes of archaeological excavation, analysis, and interpretation. These same site-specific reproductions are available for purchase in the adjacent gift shop.

With the addition of these new components, community members receive further training and employment opportunities as tour guides, heritage gardeners, living history interpreters, and retail staff. Local artists are commissioned to produce a variety of sitespecific objects for sale in the gift shop, including ceramics, jewellery, clothing, and paintings. Local gardening groups participate in the planting and maintenance of the three gardens, and the Ferryland Historical Society and the Folk Arts Council partner with the Colony of Avalon Foundation in celebrating Ferryland-Maryland Day through a variety of onsite activities that incorporate the archaeological discoveries. 
Local businesses flourish. Since 1995, the number of nearby bed-and-breakfasts has increased from one to four. Entrepreneurs utilize the popularity of the archaeological site and its thousands of annual visitors to open restaurants and other cultural venues, such as the Colony Cafe, the Lighthouse Picnics, the Tetley Tea Room, and the Southern Shore Dinner Theatre. All provide local employment as well as an opportunity to highlight the scenic beauty and unique history and folklore of the Ferryland area.

In retrospect, it is within the context of growth and diversification in archaeological tourism that we see two distinct trajectories in staff employment, retention, and involvement. On one path, we have a core group of employees who remained with the project, even when Newfoundland's economy improved and wellpaying jobs in the oil industry were readily available. For this group, the archaeological site and its associated collections instill a deep appreciation of their community's history and pride of place. On a personal and professional level, our core staff are invested in and identify with this project and as such remain active stewards of the archaeological site and its associated infrastructure year-round, despite the fact that we can only provide seasonal employment.

On the other path, we have local high school and postsecondary students who work for several summers but then move on to complete a degree or trade training and gain full-time employment. It is worth noting that some pursued undergraduate and graduate degrees in archaeology, history, or folklore. Despite the relatively brief duration of employment, this group's bond with the archaeological project and its core staff endured. Many paid forward their positive archaeological experiences by later volunteering their time and expertise on the Foundation's Board of Directors, or by contributing in other ways through donations and/or promoting the site through word-of-mouth.

Promotion and positivity at the local level have provided an added benefit in the form of intra- and inter-generational staffing. Siblings and extended family members of former field and lab crews later worked as archaeological assistants, laboratory staff, tour guides, living history interpreters, or gift shop staff. On other occasions, children of early staffers were employed, or the parents of former students became interested in working on the project after hearing 
about their child's experiences on "the dig". Continuity in staffing was not restricted to local residents. MUN undergraduate students working in the field and laboratory were groomed to take supervisory positions and eventually lead roles following the retirement of James A. Tuck and Catherine Mathias, Ferryland's first site director and conservator, respectively.

The end result is a long-term exercise in relationship building, trust, and mutual respect. University faculty, staff, and students become part of the local community; community members, in turn, are integrated into every aspect of university research and outreach. The importance of camaraderie and trust for a viable and enduring community-university research partnership such as this cannot be understated. James A. Tuck provides but one small example: "Countless times these friends [community members] picked up trowels or pumps or wheelbarrows and stored them safely until the next morning; no better security could have been hired from Brinks" (TUCK, 2013, p. 270-271).

An increase in local and regional visibility afforded by community-based research has borne unexpected fruit by way of improved communication and interaction with avocational archaeologists, sport divers, and recreational metal detectorists. Open dialogue with these groups - all of whom impact archaeological resources to a greater or lesser degree - should be viewed as a means to gain additional insight into buried or submerged cultural remains, as well as an opportunity to promote careful recording or preservation of the same. Several new archaeological sites around the Avalon Peninsula and beyond have been identified as a result, one of which was later surveyed and excavated in collaboration with the recreational metal detectorist who first found it (VENOVCEVS, 2016). Instead of isolating or denigrating this oft-maligned group of stakeholders, we need to find ways, when appropriate, to better educate and assimilate them into the study of the past.

From a research and training standpoint, the Ferryland archaeology project has proven to be an immense benefit to archaeology faculty, graduate students, and undergraduate students at Memorial University, as well as to archaeological conservators at Fleming College and Queen's University. Our ongoing efforts have led to two post-doctoral fellowships, three $\mathrm{PhD}$ dissertations, 20 
master's theses, and 12 honours essays, and we have hosted 20 conservation interns and provided hands-on-training for more than 100 undergraduate students.

Despite all of the positive things happening at Ferryland, archaeologically based heritage attractions such as this cannot and should not remain stagnant. To survive and to flourish, we must evolve. Starting in 2014, we embarked upon the next stage of this community-university partnership, one that involves a greater variety of experiences and opportunities for visitors and locals of all ages and interests. While still maintaining the core experience of the ongoing archaeological investigation and interpretation, visitors can now participate in further educational and experiential learning opportunities, such as working alongside dig staff as part of the Archaeologist for a Day program or attending one of several annual public lectures. The general public are challenged to recreate a colonial recipe with the weekly program The Great Colonial Cook Off, while children participate in scavenger hunts and artifact identifications as part of the popular Baltimore's Backpacks program. 
Figure 2

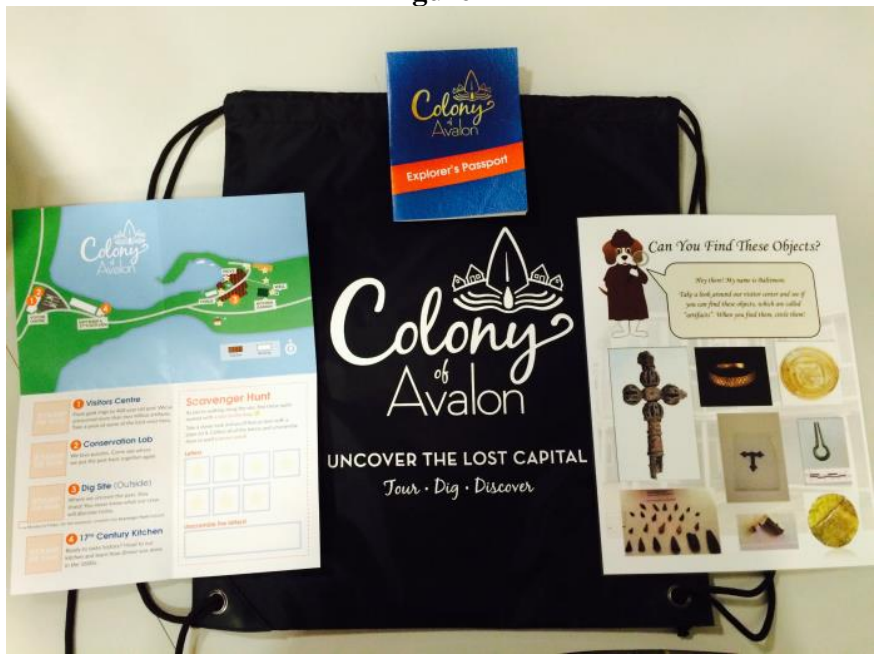

"Explorer's Passport," on-site scavenger hunt activities, and backpack from the Colony of Avalon Foundation's Baltimore's Backpacks program. Image courtesy of the Colony of Avalon Foundation.

Further educational opportunities for children can also be found in the recently published children's book The Great Ferryland Dig (MOULAND, 2014). Finally, local knitting groups have also partnered with the Foundation on the Stitching Nine over Time project, which seeks the public's assistance in producing a large, hooked rug with nine panels, each representing an important part of Ferryland's history, largely inspired by our archaeological findings.

In the context of Ferryland, archaeology is a catalyst for social and economic change at the local and regional levels. It is a source of pride for the affiliated academic institution as well as for members of the community. These kinds of long-term archaeological investigations enrich the lives of everyone involved; they provide a collective sense of identity and, probably most important, a renewed sense of optimism for the future. 


\section{Case Study 2: Archaeology with the People of NunatuKavut}

In 2001, after a 13-year absence, a new generation of Memorial University archaeologists began work in coastal Labrador. In the interim, the cultural landscape of this region had been transforming. Inuit, Inuit-Métis, and Innu had made varying degrees of progress in their quest for provincial and federal recognition and had become more engaged in vetting the work of outside researchers. At first, interactions between archaeologists and these communities were basic and aimed to simply keep communities informed of research results through presentations and school visits, while allowing relationships of trust to develop. In 2006, we received the first formal request for a research partnership from the Labrador Inuit-Métis Nation (now the NunatuKavut Community Council).

Following the excavation of a small Inuit winter village near Cartwright, Labrador, the Inuit-Métis approached Memorial archaeologists to help them learn more about Inuit history in southern Labrador. The Inuit-Métis trace their ancestry to the eighteenth- and nineteenth-century marriages of Inuit women and European settlers. By 2006, their land claims case was in development, and their legal team had determined the need to make a case for the continuity of Inuit occupation in southern Labrador because their oral traditions alone would not satisfy the provincial and federal Canadian court systems. Unfortunately, both archaeological and historical research in the region up until that time had been limited. Previously published literature made it impossible to be certain if the Inuit had ever resided in southern Labrador and did not address how Inuit-Métis ethnogenesis developed (RANKIN and CROMPTON, 2013).

We initiated the project with a retreat that brought together Inuit-Métis leadership and community members from southern Labrador, as well as scholars with an interest in the history of occupation of the region. Over four days, we collectively drafted a research plan that ultimately led to a successful application to the Social Sciences and Humanities Research Council (SSHRC) of Canada for a five-year, million-dollar project. There were many 
concerns expressed by the academics upon entering the partnership, not the least of which was the inability to predict what, if any, archaeology might be found to support the Inuit-Métis claim. In the same vein, we fretted over our role as social advocates; none of the academics involved in the project were trained social strategists, and we wondered how seriously our research would be taken by the academic and legal communities if it were perceived as such. However, it became clear at the retreat that what the Inuit-Métis wanted from this particular partnership was for us to undertake traditional academic research and disseminate the results following normal academic procedures, in order to make their history more accessible to the widest possible audience and to provide them with the background context required for their land claim. All parties strove to create a research project that would include a variety of tangible outcomes for both the Indigenous community and the academic partners, including specialist and general audience publications; accessible research tools, such as websites; skills training; films; and educational resources that would be valuable to the local Inuit-Métis communities regardless of the results of the archaeology.

We need not have worried. From the beginning, the InuitMétis told us, "We know who we are." It was not long before we discovered ways to demonstrate this history archaeologically. By the end of the project, more than 40 Inuit and Inuit-Métis sites had been identified in southern Labrador, of which 10 had been subject to intensive excavation. The research has contributed to the establishment of a chronology of Inuit occupation in the region and has demonstrated the manner in which Inuit-Métis ethnogenesis occurred (KENNEDY, 2014; RANKIN et al., 2015). This information is now being integrated into land claims documentation by the InuitMétis and their lawyers. However, it was the other initiatives we put in place which made the partnership thrive, built lasting relationships between communities and academic researchers, and heightened the sense of shared identity in the various communities represented by the Labrador Inuit-Métis Association.

The partnership emphasized educational initiatives from the beginning. Between 2009 and 2014, we worked with the various provincial school boards to have Inuit-Métis people recognized at all 
levels of the history and social studies curricula. This community is now represented in all the relevant textbooks in the province. We also ran school workshops throughout Inuit-Métis territory. Younger students learned to replicate traditional artifacts, while high schoollevel students (and their teachers) were trained in movie production and editing so that each graduating class produced movies with cultural themes. Various members of the team produced websites, but the central project website, Understanding the Past to Build the Future (www.mun.ca/labmetis), allowed students and teachers to directly download all project reports and publications, as well as pictures of artifacts and historical images of their communities. An interactive exploration of an Inuit winter house, interviews with elders, and family trees based on each of the original European/Inuit families were also featured. To this day, we continue to have at least 2000 site visits per month, with the majority coming from Labrador as locals access information relevant to their own history. Our final contribution to education, due in 2018-2019, , is "Lab-Life," a virtual world portal allowing teachers and students to explore the historic Inuit-Métis world of southern Labrador in an online game format.

Skills training was also an important element of the partnership. Each summer, high school students from Inuit-Métis communities worked on archaeological excavations and in our field laboratories. The goal was not to create a new generation of InuitMétis archaeologists, but to expose students to team-building skills and enhance self-confidence. Every one of the 12 students we employed continued on to post-secondary education, which exceeded our expectations given the generally low graduation rate of InuitMétis high school students in the region. Furthermore, all of those students have remained in Métis communities, building local capacity. We also worked closely with the fledging tourism industry in the region, providing destination stops at our excavations for boat and kayak tours and developing heritage-interpretation skills with those involved in the industry to enhance economic opportunities. We also developed products, such as heritage-based placemats requested by local restaurants, to promote local culture and destinations. 


\section{Figure 3}

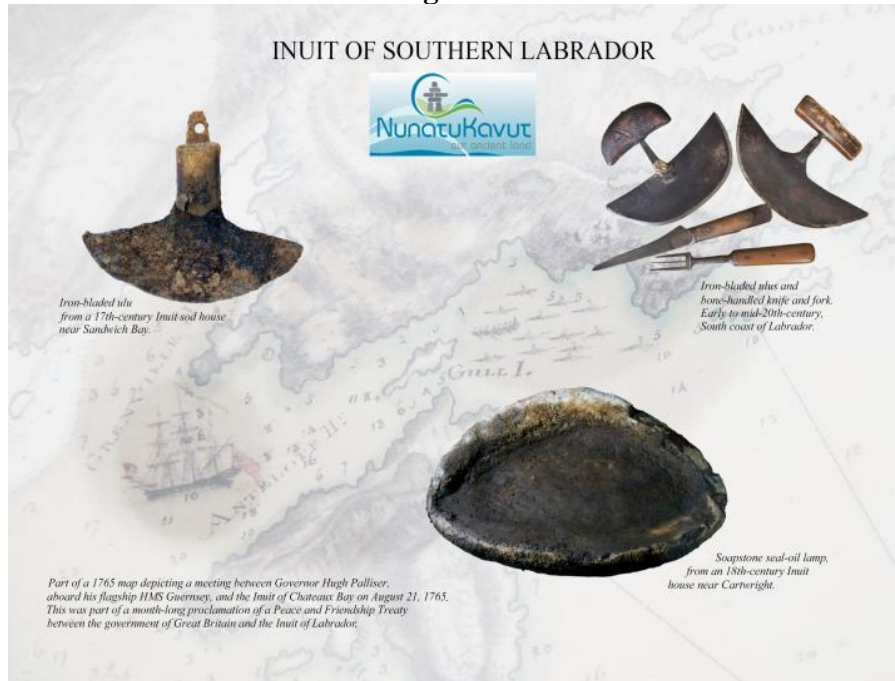

Heritage placemat requested by the hospitality providers in Inuit-Métis communities. Image courtesy of the Understanding the Past to Build the Future Project.

Finally, in addition to creating academic publications that brought awareness of our research to historical scholars, we publicized research for a general audience through radio, television, newspaper, and magazine articles and the production of two films. One of these films, The People of NunatuKavut, has been accepted to various national and international film festivals and was recently broadcast by the Canadian Broadcasting Corporation to a television audience of more than 60,000 Canadians. The Inuit-Métis story is now widely known and accessible. Interestingly, the academic publications, which include three books, are among the most soughtafter products of the research in Inuit-Métis communities, as locals recognize their own history and the contributions they made toward its dissemination.

Together, these outcomes delivered what the community wanted from the research: data which could be integrated into their land claims case, identity-building tools to be used by their members, 
and media resources to create an external awareness of their culture. Throughout this process, the Inuit-Métis continued on their own journey of self-discovery. They now proudly self-identify as Southern Inuit, and their membership is represented by the NunatuKavut Community Council, which has established its own research wing and continues to build and develop new research partnerships as their land claims enter the final stages. As archaeologists, we also benefitted; at the academic level, we made an influential contribution to the culture history of a people and region, but, more importantly, we saw firsthand the significance that well-derived partnered research can have in local communities and the opportunities for social justice that our skills can facilitate. This partnership established a pattern of Indigenous community engagement that we continue to build and expand.

\section{Case Study 3: Partnering with the Nunatsiavut Government}

In 2015, archaeologists helped establish a new and ongoing partnership with Inuit in northern Labrador. Tradition and Transition Among the Labrador Inuit is a five-year SSHRC partnership between a large, interdisciplinary group of scholars and the Nunatsiavut Government. In 2015, this Indigenous government celebrated its tenth anniversary, and it is now in the process of implementing a number of wide-ranging Inuit-driven policies, including a regional tourism strategy, the development of the new Illusuak Cultural Centre, and local responses to the recommendations of the Truth and Reconciliation Commission of Canada. Hoping to embed both traditional Inuit ideals and Western research results in their endeavours, the Nunatsiavut Government initiated this partnership to draw on the skills and expertise of Memorial University faculty and graduate students to develop, combine, and compile these data. At the same time, academics realized that many of our own scholars were nearing retirement age and there was a real need to both publish 
extant data and reinvigorate humanities and social science research in northern Labrador. The overall aim of the project is one of reconciliation, which brings local knowledge bearers together as partners with academic researchers to share data and interpretations openly, respectfully, and equally. Only archaeological projects requested by the communities, and vetted by an Inuit-driven partnership-management board, are pursued. Thus, archaeologists are playing numerous roles, by excavating and monitoring Inuit sites at risk due to climate change or mandated as tourist centres; offering skills development; helping integrate oral histories into the narratives of past Inuit lifeways; providing access to artifacts and literature; assisting with the development of territorial heritage and tourism policies; and, perhaps most significant, establishing practices which allow for knowledge transfer between youth and elders - both Inuit and academic.

Inuit sites near Rigolet, Hopedale, and Nain are being excavated to expand local tourism strategies, as the Nunatsiavut Government increasingly opens northern Labrador to cruise ship traffic and invites visitors to the co-managed Torngat Mountain and Mealy Mountain national parks. To date, excavation has taken place at the Double Mer Point site, near Rigolet. In preparation for an increase in tourists associated with the new Mealy Mountain National Park, the community of Rigolet wants to offer culture-based tourism options to visitors. The site of Double Mer Point lies at the end of a nine-kilometre boardwalk constructed by the town to take hikers through a variety of local coastal ecosystems. The site itself, a late eighteenth- to early nineteenth-century Inuit winter village, was likely the last settlement occupied by the Inuit in a traditional fashion before the establishment of the modern community of Rigolet. For the past three years, the excavation has been advertised as a tourist destination, and a working lab has been established near the Rigolet ferry dock for tourists and community members to view the finds daily. Because of its central location and open-door policy, the laboratory has become a hub of community activity where elders and youth meet daily to examine artifacts and help archaeologists interpret the finds. 
Figure 4

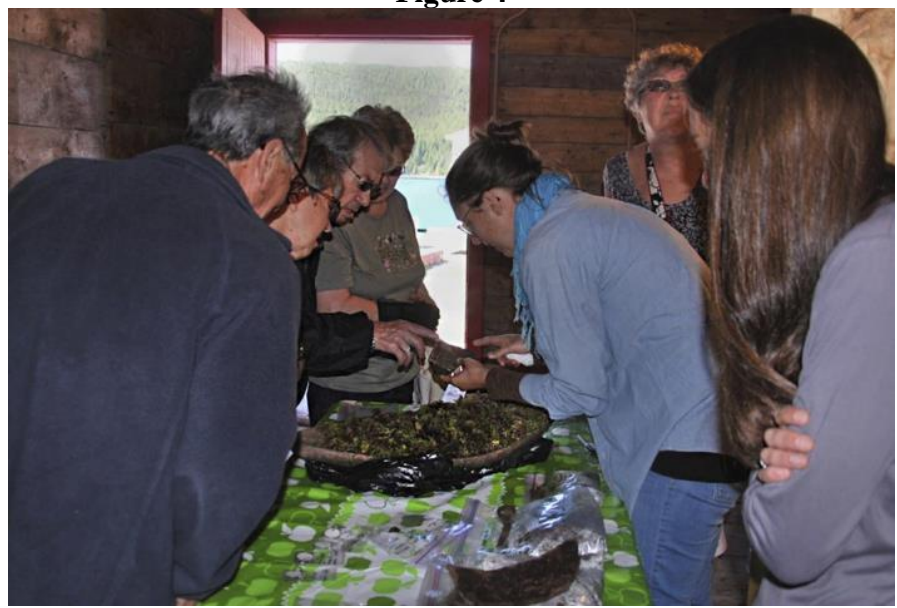

Interactions in the archaeology lab in the Net Loft Museum, Rigolet, Labrador. Image courtesy of the Tradition \& Transition Partnership.

Access to the artifacts sets the scene for storytelling and knowledge transfer between youth and elders. Undergraduate and graduate archaeology students work side by side with high school, college, and university students from the local community in the lab and at excavations and, through these daily interactions, learn the significance and impacts of locally based partnerships as well as more traditional archaeological skills. There are plans to reconstruct the village upon completion of the excavation and to provide local interpretation to visitors. Local students, along with archaeologists and elders, will develop the format for interpretation. In the meantime, the Aboriginal Peoples Television Network chose to highlight the excavation of the site in their new program Wild Archaeology, adding further publicity.

The partnership will also be supporting the work of many graduate students undertaking a full range of archaeological work, from traditional excavations, like those underway at Double Mer Point, to archaeology policy development and reconciliation initiatives. At Double Mer Point, master's student Kayley Sherret is working with the community to provide $3 \mathrm{D}$ replicas of artifacts for 
display in the town. $\mathrm{PhD}$ student Jamie Brake is currently the Nunatsiavut Government archaeologist, and his dissertation will result in the first Nunatsiavut-driven archaeological policy, which seeks to integrate typical resource management protocols with traditional Inuit knowledge, such as the protection of important landscapes. His dissertation will be subject not only to traditional academic protocols, but also to vetting through community consultation prior to implementation. Another PhD student, Michelle Davies, has begun work on the Hebron Family Archaeology Project, designed to map and excavate twentieth-century homes in Hebron with Inuit elders who were forced to abandon the community when it was closed by the Moravian missionaries in 1959. This project is part of a community healing program initiated by the Nunatsiavut Government and supported by their Department of Health and Social Development. Over the next three seasons, the program will involve both elders and youth in an effort to confront the multigenerational trauma associated with relocation policies of Canadian federal and provincial governments in the past. Other archaeologists will monitor remote sites in danger of destruction through storm surge and peat degradation associated with climate change, create GIS maps of local toponyms, and integrate oral histories and archaeological data concerning the arrival and expansion of Inuit in Labrador.

All the archaeological work will be accessible to the Nunatsiavut communities on the project website, on Facebook, and in publications. As well, many of the details and artifacts will be integrated into exhibits at the Illusuak Cultural Centre/ Illusuak IlikKusiligijingita SuliaKapvinga, or through travelling exhibits and locally established data hubs over the next five years.

Most importantly, this work is about reconciliation. Youth and elders from Inuit communities and academia are coming together to transfer, perpetuate, and expand local knowledge. This partnership also establishes new protocols for community research that prioritizes and respects local goals and decision making and where the value of traditional knowledge and academic knowledge is equalized in hopes that youth, both Inuit and academic, will embrace a new way forward. 


\section{Discussion and Conclusion}

What have these experiences taught us? For one, it is imperative that archaeologists be sensitive to and cognizant of the varying perspectives and interests of community members. Our interpretations - our storytelling - cannot be holistic or broadly meaningful unless we incorporate multiple voices. The archaeological study of the past is multifaceted, and academia is but one face among many. Archaeologists and community members often have disparate agendas (POPE and MILLS, 2007, p. 183), and we sometimes see things from different, occasionally contradictory perspectives: What is important? What should be preserved and presented to the public? What can be discounted as a superfluous theory or idea? But whose history are we really representing here, and who is our intended audience? The power of community archaeology lies in its ability to serve as both a grounding mechanism and a means of mutual learning and sharing. Simply put, "the involvement of local communities in archaeological investigations from the outset results in better archaeology" (MOSER et al., 2002, p. 222) and in better archaeologists.

Community-based archaeology also takes outreach and dissemination in exciting new directions. As competent and capable as we believe we are as academics, we should not operate in isolation. Community-driven ideas and initiatives, including heritage-based placemats for restaurants, interactive onsite children's activities, and online gaming based on archaeological finds, are all non-traditional forms of archaeological outreach and dissemination. They are made possible thanks to the diverse backgrounds and the personal and professional experiences of community members. Educational initiatives and resources are likewise identified as being a highly neglected feature of community archaeology (TULLY, 2007, p. 168) but have been integrated into the above-mentioned projects though film, children's books, updated history and social studies curricula, and school workshops in Indigenous territories. These types of educational initiatives are best achieved, and most influential, when developed in a collaborative context. 
Important among Indigenous communities, but also other communities marginalized by geography or economic circumstance, is that archaeology has the potential to contribute to social justice, by bringing skills training, by emphasizing social cohesion, and pride in their heritage to communities that have felt powerless. An archaeology of reconciliation places power back in the hands of the community and brings community members together through a sense of ownership of their heritage (TULLY, 2007:158). It also allows archaeologists to use their skills and knowledge in new ways that benefit local communities; compiling and archiving data and making it accessible might seem basic, but this is often beyond the capacity of small, remote communities. However, access to archaeological materials is one way to generate further communication and knowledge transfer, not only between archaeologists and communities, but also between elders and youth within communities, to keep history and traditions alive.

To conclude, community-based archaeology has a long history in the province of Newfoundland and Labrador, and Memorial University has been part of the process for nearly 40 years. Throughout this time, there has been an increasing awareness and acceptance of the ways in which archaeology and traditional knowledge can overlap. In turn, this has increased the number and types of questions we have sought to address together and has pushed archaeology in new, socially relevant directions. Archaeological heritage and its interpretation and dissemination are no longer the exclusive purview of academia. At Memorial University, almost all of our students participate in community archaeologies over the course of their programs, and the relationship between archaeologists and communities in Newfoundland and Labrador is balanced as we collectively move toward many common goals. 


\section{Acknowledgements}

We would like to thank Allison Bain and Réginald Auger (Université Laval) for organizing the "What does heritage change? Case studies in archaeology" session as part of the 2016 ACHS conference, and for their efforts in producing and editing these conference proceedings. Two anonymous reviewers provided useful suggestions to improve this manuscript, for which we are grateful. Any omissions or errors are ours alone.

\section{Bibliography}

ATALAY, Sonya. Community-based Archaeology: Research with, by and for Indigenous and Local Communities. Berkeley: University of California Press, 2012.

AUGUSTINE, Madeline, TURNBULL, Christopher, ALLEN, Patricia \& Pamela WARD. To Hold it in My Hand. In: John H. JAMESON \& Sherene BAUGHER (eds.). Past Meets Present: Archaeologists Partnering with Museum Curators, Teachers, and Community Groups. New York: Springer, 2007.

BROOKS, Meagan. Reconnecting the Present with its Past: The Doukhobor Pit House Public Archaeology Project. In: Barbara J. LITTLE \& Paul A. SHACKEL (eds.). Archaeology as a Tool of Civic Engagement. Plymouth: AltaMira Press, 2007.

DOLAN, A.H., TAYLOR, M., NEIS, B., OMMER, R., EYLES, J., SCHNEIDER, D. \& B. Montevecchi. Restructuring and Health in Canadian Coastal Communities. EcoHealth, n. 2 (3), 2005, p. 195208.

FRIESEN, T. M. Analogues at Iqaluktuuq: the social context of archaeological inference in Nunavut, Arctic Canada. World Archaeology, n. 34 (2), 2002, p. 330-345. 
GAULTON, Barry C. The commercial development of Newfoundland's English Shore: The Kirke Family at Ferryland (1638-1696). In: Peter E. POPE \& Shannon LEWIS-SIMPSON (eds.). Exploring Atlantic Transitions: Archaeologies of Permanence and Transience in New Found Lands. Society for Post-Medieval Archaeology Monograph no. 7. Woodbridge: Boydell and Brewer, 2013.

GAULTON, Barry C. \& TUCK, James A. Archaeology at Ferryland 1621-1696. In: James A. TUCK \& Barry C. GAULTON (eds.). Avalon Chronicles 8: The English in America 1497-1696. St. John's: The Colony of Avalon Foundation, 2003.

GIEN, L. Land and Sea Connection: The East Coast Fishery Closure, Unemployment and Health. Canadian Journal of Public Health $\mathrm{n}$. 91(2), p. 121-124, 2000.

JAMESON, John H. \& BAUGHER, Sherene. Public Interpretation, Outreach, and Partnering: An Introduction. In: John H. JAMESON \& Sherene BAUGHER (eds.). Past Meets Present: Archaeologists Partnering with Museum Curators, Teachers, and Community Groups. New York: Springer, 2007.

KENNEDY, John (ed.). History and Renewal of Labrador's InuitMétis. St. John's, ISER Press, 2014.

KIRK, Ruth \& DAUGHERTY, Richard D. Exploring Washington Archaeology. Seattle: University of Washington Press, 1978.

MARSHALL, Y. What is Community Archaeology? World Archaeology, n. 34 (2), 2002, p. 211-219.

Memorial University of Newfoundland. Vision, Mission and Values. Statement from the Office of the President. www.mun.ca/president/home/vision.php, 2013. Accessed November 13, 2016.

MOSER, S., GLAZIER, D., PHILLIPS, J., EL NEMR, L.N., MOUSA, M. S., AIESH, R.N., RICHARDSON, S., CONNER, A. \& SEYMOUR, M. Transforming Archaeology through Practice: Strategies for Collaborative Archaeology and the Community 
Archaeology Project at Quseir, Egypt. World Archaeology, n. 34(2), 2002, p. 220-248.

MOULAND, Necie. The Great Ferryland Dig. St. John's: DCR Publishing, 2014.

POPE, Peter E. \& MILLS, Stephen F. Outport Archaeology: Community Archaeology in Newfoundland. In: John H. JAMESON \& Sherene BAUGHER (eds.). Past Meets Present: Archaeologists Partnering with Museum Curators, Teachers, and Community Groups. New York: Springer, 2007.

RANKIN, L. K. \& CROMPTON, A. The Labrador Metis and the Politics of Identity: Understanding the Archaeological Past to Negotiate a Sustainable Future. International Journal of Heritage and Sustainable Development, n.7 (3), 2013, p. 71-79.

RANKIN, L.K. \& STOPP, M. \& CROMPTON, A. (eds.). The Inuit in Southern Labrador. Études Inuit Studies, n. 39 (1), 2015.

RICHARDSON, L \& ALMANSA-SÁNCHEZ J. Do you even know what public archaeology is? Trends, theory, practice, ethics. World Archaeology, n. 47(2), 2015, p.194-211.

SPECTOR, J. D. What this Awl Means: Feminist Archaeology at a Wahpeton Dakota Village. St. Paul: Minnesota Historical Society Press, 1993.

TUCK, J. A. Archaeology at Ferryland, Newfoundland. Newfoundland Studies, special issue Archaeology in Newfoundland and Labrador, n. 9 (2), 1993, p. 294-310.

. Ferryland's First Settlers (and a Dog Story). In: Peter E. POPE \& Shannon LEWIS-SIMPSON (eds). Exploring Atlantic Transitions: Archaeologies of Permanence and Transience in New Found Lands. Society for Post-Medieval Archaeology Monograph no. 7. Woodbridge: Boydell and Brewer, 2013.

TUCK, James A. \& GAULTON, Barry C. The evolution of a seventeenth-century manor. In: E. KLINGELHOFER (ed). A Glorious Empire: Archaeology and the Tudor-Stuart Atlantic World. Oxford: Oxbow Books, 2013. 
TULLY, G. Community Archaeology: general methods and standards of practice. Public Archaeology, n. 6 (2), 2007, p.155-187.

VENOVCEVS, Anatolijs. Newfoundland Winter House Investigation - Final Report Permit No. 15.10. Submitted to the Provincial Archaeology Office, Department of Business, Tourism, Culture and Rural Development, 2016.

WEBB, Jeff A. Observing the Outports: Describing Newfoundland Culture, 1950-1980. Toronto, University of Toronto Press, 2015.

RECEBIDO EM: 01/06/2018 APROVADO EM: 12/07/2018 